\title{
Paleogeographic implications of the Shanita- Hemigordius fauna (Permian foraminifer) in the reconstruction of Permian Tethys
}

\author{
1 Institute of Geology, Chinese Academy of Geological Sciences, 26 Baiwanzhuang Road, Beijing 100037, P. R. China \\ 2 Department of Earth Sciences, Nanjing University, Nanjing, 210093, P. R. China
}

\begin{abstract}
The Permian foraminifer Shanita is a genus of special paleobiogeographic importance. Current data indicate that this genus occurs in peninsular Thailand, Shan States of Burma, western Yunnan and northwestern Tibet of China, south Pamir of Tajikistan, South Afghanistan, Kuh-e Gahkum area of Iran, Transcaucasus, Pinarbasi area of Turkey, and the Saiq Plateau of Oman. Studies also show that several species of Hemigordius usually coexist with Shanita, and form a peculiar Shanita-Hemigordius fauna.

Localities of the Shanita-Hemigordius fauna that have been found hitherto are confined on Gondwanaderived blocks, which constitute a strip starting from peninsular Thailand and extending northwestwards and westwards to Turkey. This fauna is considered as another Permian palaeontological marker of marginal Gondwana environment.
\end{abstract}

\section{Introduction}

The genus Shanita, a pillared miliolacean foraminifer, was named by Brönnimann, Whittaker \& Zaninetti (1978). The type species, Shanita amosi Brönnimann, Whittaker \& Zaninetti, 1978 was found from the Permian dolomite in the Southern Shan States of Myanmar, and is associated primarily with species of Hemigordius, including Hemigordius renzi (Reichel) (formerly Hemigordiopsis renzi Reichel; Brönnimann et al., 1978 regarded Hemigordiopsis Reichel, 1945 as a junior synonym of Hemigordius Schubert, 1908). Brönnimann, et al. (1978) also identified Shanita intercalaria from the Khlong Pha Saeng valley in southern Thailand. The Staffella zisongzhenensis (Sheng) described by Montenat et al. (1976) from the Saiq Plateau of Oman was revised by Brönnimann et al. (1978) as Shanita amosi. Zaninetti et al. $(1979,1982)$ reported two additional Shanita localities, the Kuh-e Gahkum area in Iran and Pinarbasi area in Turkey. In the 1980s, Shanita was found in western Yunnan (Sheng \& He, 1983) and the Rutog area (Nie \& Song 1985) of China, and Transcaucasus (Pronina, G. P., 1988). In the 1990s, Leven $(1991,1997)$ reported Shanita in Pamir and in South Afghanistan. In almost all of these localities species of Hemigordius were found to coexist with Shanita, and they together form a Shanita-Hemigordius fauna.

Recently, we found abundant specimens of Shanita and Hemigordius in the so-called "Cracked Limestone" in the northern Baoshan Block, western Yunnan, China (Yang et al., 2004). Fossils of these two genera are extremely abundant and form a typical
Shanita-Hemigordius fauna, including Shanita amosi, S. chagouensis, Hemigordius renzi and $H$. biconcavus.

The localities of the Shanita-Hemigordius fauna that have been found hitherto are confined on blocks, which constitute a strip starting from peninsular Thailand and extending northwestwards and westwards to Turkey. Such a unique distribution pattern must have resulted from a specific paleogeographic configuration.

\section{Regional distribution}

\section{Peninsular Thailand}

Brönnimann et al. (1978) described Shanita interclaria Brönnimann, Whittaker \& Zaninetti from the valley of the Khlong Pha Saeng, about $90 \mathrm{~km} \mathrm{NE}$ of the tin mining center of Phuket, where Shanita coexists with other small foraminifers, such as Hemigordius cf. renzi (Reichel) and some other species of Hemigordius, as well as Pachyphloia and Nankinella. They also noted that the rock containing the fauna was atypical of the Rat Buri Limestone Formation. Ingavat (1984) reported two other localities, namely, Khao Wang Mo Kaeng south of Phang-Nga and Khao Nang north of Surat Thani, both with similar foraminiferal faunas. Dawson et al. (1993) also described the Shanita fauna from the Chumphon, Phangna and Surat Thani areas. They considered the age of this fauna is latest Murgabian to early Dzhulfian.

\section{Myanmar}

The genus Shanita Brönnimann, Whittaker \& Zaninetti was named by Brönnimann et al. (1978), based on specimens from the Permian Nwabangyi Dolomite Formation in the Neyaunggaó Yengan area, the Southern Shan States of eastern Myanmar, about 100 km SSE of Mandalay. The type species Shanita amosi Brönnimann, Whittaker \& Zaninetti is associated primarily with species of Hemigordius, including H. renzi (Reichel). Fusulinids occurring in the same horizon are Reichelina and Nankinella. Whittaker et al. (1979) studied Shanita amosi and the associated foraminifers and algae from the Nwabangyi Dolomite Formation of two new localities in the same area of the type locality of Shanita amosi. Due to the lack of fossils, which can indicate a more definite age, Brönnimann et al. (1978) assigned this fauna, after regional correlation, to the Tatarian (Captitanian to early Wuchiapingian or Midian to early Dzhulfian).

\section{Western Yunnan, China}

Sheng \& He (1983) described Shanita amosi and associated $S$. chagouensis Sheng \& He, Hemigordius zaninettiae Altiner, H. renzi (Reichel), and $H$. biconcavus (Wang) in western Yunnan, China, based on the specimens collected by Geological Survey of Yunnan from one locality in the northern Tengchong Block and two localities in the southern Baoshan Block. They considered Hemigodiopsis Reichel, 1945 as a subgenus of Hemigodius Schubert, 1908. Recently, 


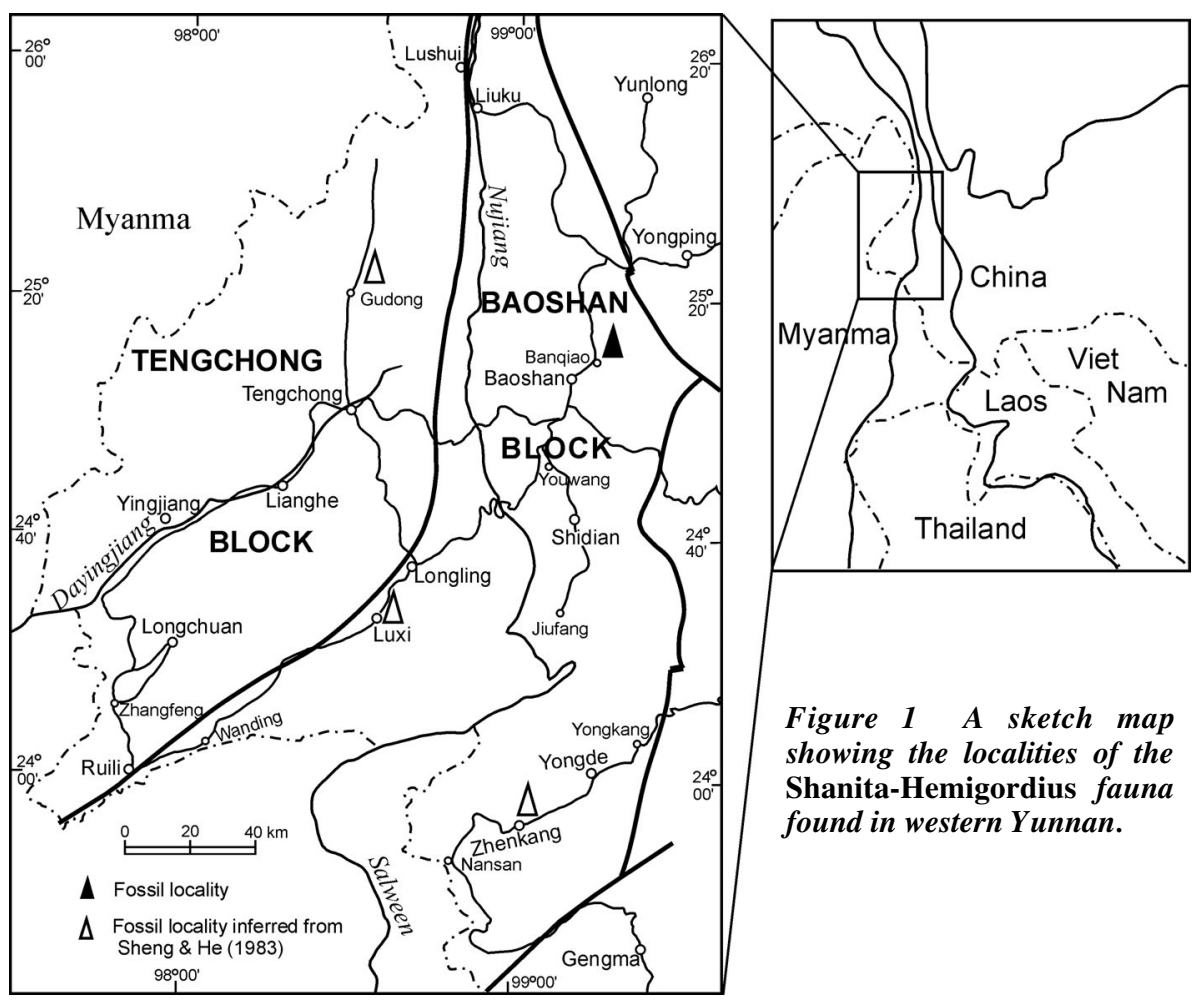

sions described by Leven (1993), species of Shanita in west Pshart occur in a position higher than the beds containing Hemigordius and the associated fusulinids, which are dominated by Chusenella, Kahlerina, Yangchienia, Nankinella, Sphaerulina, and Neoschwagerina. However, the boundary between the two units is not a continuous sedimentary contact. According to Leven, Shanita-bearing beds is probably Dzhulfian in age. However, Leven (1991) noted that the Pamir's representatives of Shanita look more advanced in evolutionary development (large number whorls of coiling and large size of tests) in comparison with Shanita found together with "Hemigordiopsis".

\section{Afghanistan}

In the area southeast of Hirat (Leven, 1997), elements of Shanita occur in two limestones separated by an unevenly scoured surface. The upper limestone contains profuse Shanita sp.; the lower limestone contains besides Hemigordius renzi and Shanita sp., abundant Rauserella sphaeroidea Sosnia, Pseudoendothyra sp., Staffella sp., Sphaerulina sp., Dunbaruna sp., Neoshcwagerina cf. haydeni Dutkevitch, Tuberitina sp., Glomospira sp., Globivalvulina sp., Glomospirella

we found abundant elements of Shanita and Hemigordius in the northern Baoshan Block (Yang et al., 2004) (Figure 1). This is the first time that Shanita is discovered in this area. In this locality fossils of Shanita and Hemigordius are extremely rich and form a typical ShanitaHemigordius fauna, including Shanita amosi, S. chagouensis, Hemigordius renzi and $H$. biconcavus (Yang et al., 2004). The carbonate containing these fossils is the so-called "Cracked Limestone", which earned its name as it often breaks up into rock pieces of $2-5 \mathrm{~cm}$ in size at outcrops, and is composed primarily of foraminifer-rich algal grainstone with localized small-scale laminations (Figure 2). Similar to the situation in the Shan States of Myanmar, fossils with great stratigraphic significance have not been found in the "Cracked Limestone". An age of late Middle Permian for the Shanita-Hemigordius fauna was assigned, based on regional correlation (Yang et al., 2004).

\section{Northwestern Tibet, China}

Wang (1982) first reported Hemigordius biconcavus (Wang) from the Rutog area, northwestern Tibet. Nie \& Song (1985) described Maokouan foraminifers from the Rutog area. According to their description, Shanita amosi, S. interclaraia, Hemigodius renzi, $H$. biconcavus occur in thick-bedded limestones and oolitic limestones, and have a relatively long stratigraphic distribution, although this could have been resulted from the relatively coarse subdivision of the section. In addition, the assemblage also comprises species of many other non-fusulinid foraminifers, as well as the fusulinids, like Neoschwagerina, Colania, Verbeekina. Nie \& Song (1985) concluded that the age of the ShanitaHemigodius assemblage should be comparable with that of the fusulinid Neoschwagerina-Yabeina zone, that is about the (late) Wordian to Capitanian in the scale of Jin et al. (1997).

\section{Pamir (Tajikistan)}

The occurrence of Shanita in Pamir was first reported by Leven (1991) from a section along the west Pshart River. He identified three species of Shanita, i.e. S. amosi, S. cff. chagouensis, and a new species $S$. pamirica Leven. In this short paper, he also reported the presence of Hemigordius renzi in a section of Kalaktash. Leven (1993) listed the foraminifers in the explanations of the sequences of west Pschart and Kalaktash. According to the successp., Neoendothyra sp., Dagmarita chanakchensis Reitlinger, Kamurana sp., Baisalina sp. Leven (1997) name the upper limestone Shanita beds, the lower Hemigodius renzi beds, although Shanita sp. also occurs in the lower limestone.

In central Afghanistan, the Parida Formation, which consists of thick-bedded dolomitic limestone and dolomite, contains barely fossils; but in one outcrop near the Chohan village, Shanita amosi and Hemigordius renzi were discovered from the top part of the formation together with other upper Midian-Dzhulfian smaller foraminifers and fusulinids, including Colaniella cf. cylindrical Miklukho-Maclay, Kahlerina sp., Nankinella sp., Reichelina changhsingensis Sheng \& Zhang and R. cf. media Miklukho-Maclay (Leven, 1997).

\section{Iran}

Zaninetti et al. (1979) reported Shanita amosi and Hemigordius renzi from a horizon in thick dolomitic limestone of the Kuh-e Gahkum section in the southern Zagros. Associated foraminifers are Hemigordius sp., Agathammina pusilla (Geinitz), Globivalvulina vonderschmiti Reichel, Reichelina sp., Staffella sp., Frondina permica Sellier de Civrieux \& Dessauvagie. Baghabani (1988) concluded, based on studies of materials from seven surface and ten subsurface sections, that the genus Shanita, represented by $S$. amosi and $S$. aff. interclaria, is an excellent marker of Midian or Abadehian rocks in the Zagros basin in south and southwest Iran.

\section{Turkey}

Zaninetti et al. (1979) reported Shanita amosi of late Murgabian age, based on the samples collected by one of the co-authors from a section near Pinarbasi in the eastern Taurus. Only a few specimens of Shanita were found in this section and the tests of Shanita amosi appear laterally compressed and split by large fractures. Associated foraminifers are a small number of Pachyphloia cukurkoyi Sellier de Civrieux \& Dessauvagie, Lunucammina postcarbonica (Spandel) Dagmarita chanakchensis Reitlinger, Globivalvulina vonderschmiti Reichel. Zaninetti et al. (1982) reported a new species of Shanita, i.e. S. bronnimmani from the eastern Taurus, and Shanita amosi, Hemigordius irregulariformis are also present in the same section. 

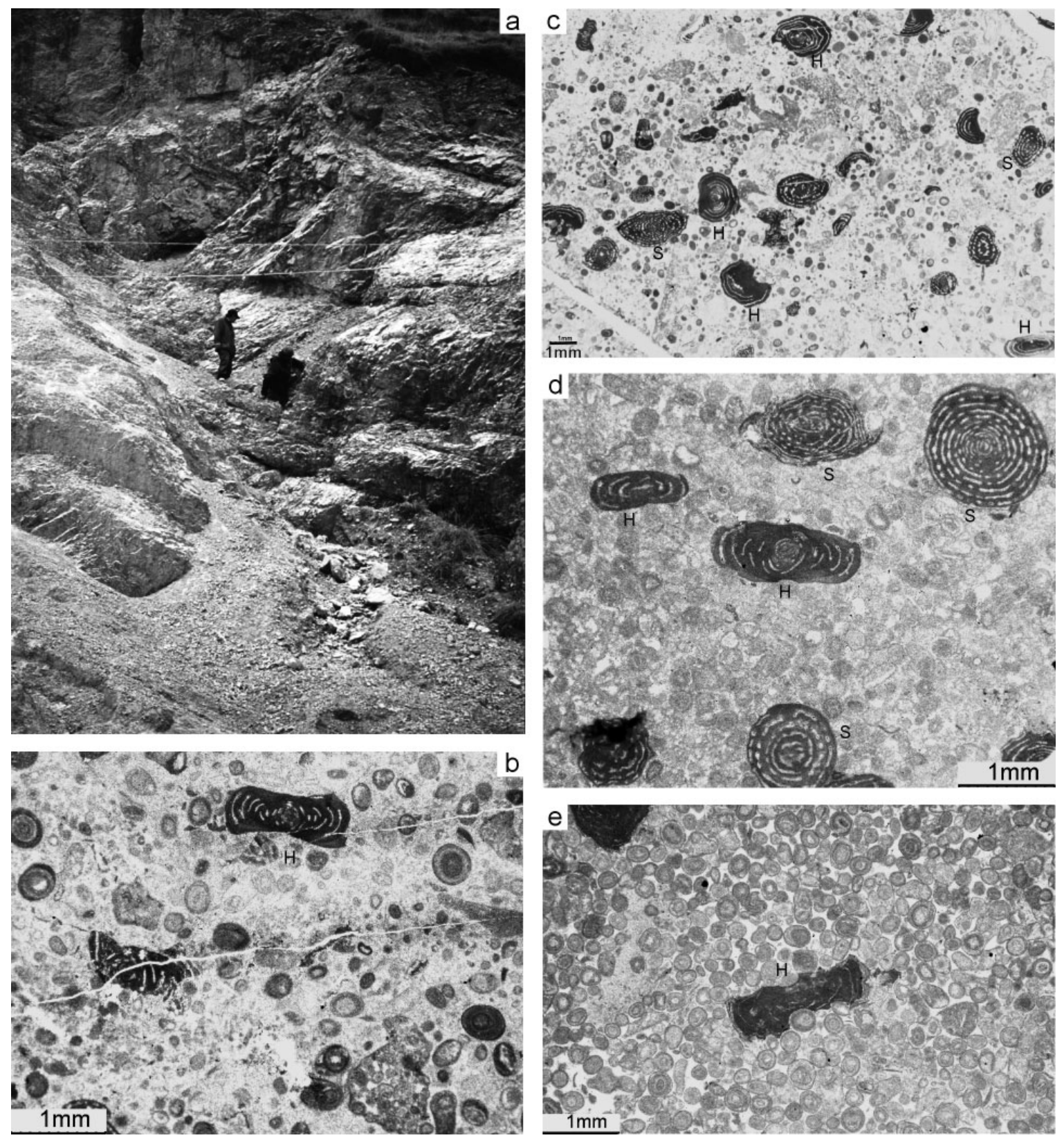

Figure 2 Photograph and photomicrographs of the so-called "Cracked Limestone" in the northern Baoshan block, western Yunnan, which contains the Shanita-Hemigordius fauna. a-outcrop; b-e-species of Shanita (S) and Hemigordius (H) in different host rocks with varying abundance of algal grains.

\section{Transcaucasus}

Pronina (1988) described the Late Permian (Murgabian to Dorashamian) smaller foraminifers of Transcaucasus. She established 12 biozones, according to the characteristics of foraminifers in this region. Shanita amosi occurs locally in the Neodiscus millioides zone, which was assigned to the lower Murgabian. Elements of Hemigodius, however, are abundant and widely distributed in the "Hemigordiopsis orientalis" zone*, which was assigned to about the middle Midian, and is four biozones higher than the Neodiscus millioides zone, according to her subdivision. This is rather unique, compared with other places where Shanita amosi occurs.

\section{Oman}

Montenat et al. (1976) reported the Permian fusulinid Staffella zisongzhenensis (Sheng) from the Saiq Plateau, Oman. Brönnimann et al. (1978) considered that the specimens are actually Shanita amosi. Besides Shanita amosi, there are other foraminifers, such as Hemigordius renzi, and the fusulinid Nankinella.

\section{Distribution of Hemigordius}

Comparing with Shanita, Hemigordius has a wider geographic distribution. The type species of Hemigodius renzi is from the Permian limestone in the Komi Kebir area of Cyprus (Reichel, 1945).

\footnotetext{
* The name Hemigordiopsis orientalis (Wang \& Sun) should be an amendment of Gansudiscus orientalis Wang \& Sun, 1973. On the other hand, Gansudiscus luquensis Wang \& Sun, 1973, G. irregularis Wang \& Sun, 1973, G. orientalis Wang \& Sun, 1973 were revised by Zaninetti et al., 1979 to be Hemigordius renzi, and by Sheng \& He, 1983 to be Hemigordius (Hemigordiopsis) renzi.
} 


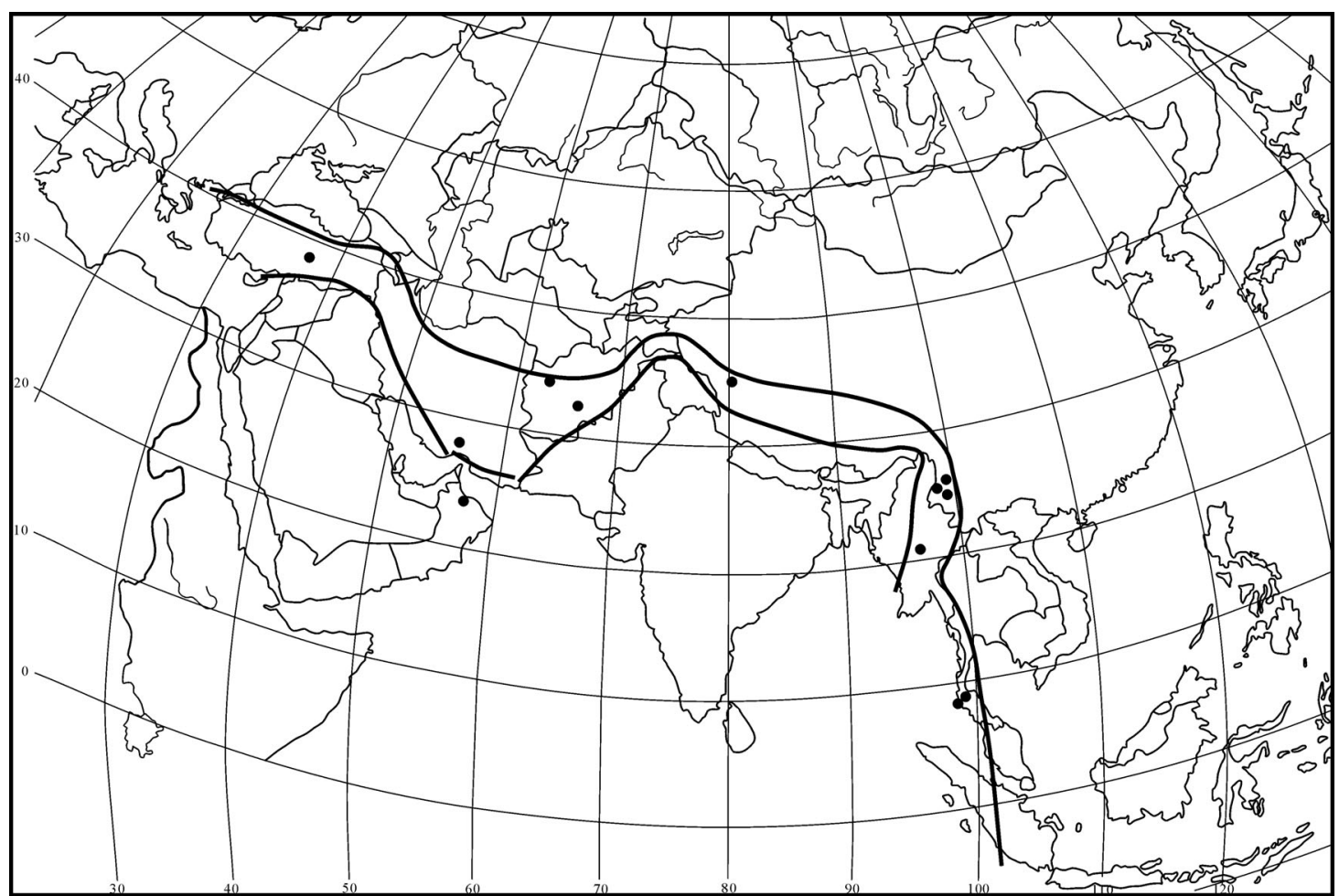

Figure 3 Distribution of known localities of the Shanita-Hemigordius fauna, which are confined mostly in a belt composed of blocks with Gondwana-affinity Permo-Carboniferous sediments and biota; one locality is on the margin of Gondwana continents (Oman).

Martinos and Reichel (1958) reported an Upper Permian assemblage with Hemigodius renzi in eastern continental Greece and on Euboea, where it occurs together with fusulinid species including Neoschwagerina cf. margaritae Deprat, $N$. cf. craticulifera Schwager, Vereekina verbeeki Geinitz. Nikitina (1969) reported Hemigordius renzi from southern Sikhote-Alin, co-existing with $H$. parvus Nikitina, $H$. speciosus Nikitina and the fusulinids Neoschwagerina craticulifera (Schwager), N. margaritae Deprat, and Yabeina inouyei Deprat. In China, Wang \& Sun (1973) described Permo-Carboniferous foraminifers from the Qinling (Tsinling). Hemigordius renzi (=Gansudiscus luquensis Wang \& Sun, G. irregularis Wang \& Sun, G. orientalis Wang \& Sun) (Zaninetti et al. 1979; Sheng \& He 1983) was found in the same horizons with Neoschwagerina megasphaerica Deprat, N. douvillei Ozawa, N. kueichowensis Sheng in the Shuixiakou Formation of Zhen'an, Shaanxi Province. Nestell \& Pronina (1997) discussed the distribution of the genus "Hemigodiopsis" and confined the age of three "Hemigodiopsis" assemblages that they had classified to the late Midian. They also mentioned the occurrence of "Hemigodopsis" in British Columbia. From all these localities Shanita has not been reported. Gargouri \& Vachard (1988) reported "Hemigordiopsis" renzi and other porcellaceous foraminfers from Jebel Tebaga of south Tunisia, where they co-exist with the late Murgabian to Midian fusulinids, including Neoschwagerina, Yabeina, Dunbarula, Chusenella. They also discussed the evolving process of Shanita from "Hemigordiopsis".

As already noted by Nestell \& Pronina (1997), Hemigordius occurs not only in southern and northern peri-Tethys, but also in the middle of Tethys, e.g. the Qinling. However, the distribution of Shanita (which is almost always accompanied by species of Hemigordius) is rather limited. The Shanita-Hemigodius fauna is therefore of more paleogeographic significance.

\section{Paleogeographic significance}

During the Permo-Carboniferous, Pangea assembling and continental margin rifting sustained a significant dynamic process. Also in this period, glaciation and associated climatologic changes resulted in the formation of characteristic sedimentary successions and distinctive biota on Gondwanan continents. The glacial, deglacial and post-glacial successions, the cold water fauna and the Glossopteris flora are three distinctive indicators of Gondwanan Permo-Carboniferous, and have been proven to be effective diagnostic properties for Gondwanan affinity deposits and biota on continental blocks.

Based on studies of Late Carboniferous to Early Permian sediments and fossils, and studies of regional geology, a group of continental blocks with Gondwana-affinity sediments and biota have been recognized. Many authors interpreted these blocks as having been derived from the margin of Gondwana (e.g. Jin, 1996, 2002, Metcalfe, 1996; Sengör, 1984; Sengör et al., 1996), although different authors defined the northern boundaries of the blocks somewhat differently. These blocks are now situated between the former Gondwanan continents and Laurasian continents or blocks (Figure 3). In Figure 3 there are two lines extending from Southeast Asia to West Asia. The upper line stands for the northern margin of blocks with Gondwana-affinity sediments and biota; most segments of it are reported faults or sutures (e.g. Altiner et al., 2000; Jin, 1996, 2002; Leven, 1993, 1997; Okay, 2000, Sengör, 1984; Sengör et al., 1988, 1996), a few segments are inferred from regional geological data. The lower line stands for the northern margin of major Gondwanan continents, which is in fact the line linking the sutures of the Himalayan orogeny.

Surprisingly, the occurrences of the Shanita-Hemigordius fauna are almost all confined on these Gondwana-derived blocks, 
except a locality (Oman) on the margin of Gondwawan continent (Figure 3). This suggests that the carbonate rocks containing the Shanita-Hemigordius fauna compose the upper Murgabian-Midian (possibly lower Dzhulfian) part of the Permian successions that start with coarse clastic (mostly glacio-marine) deposits, and the ShanitaHemigordius fauna is another palaeontological marker of marginal Gondwana environment.

However, we are in a dilemma when trying to explore the paleogeographic implications of such a distribution pattern of the Shanita-Hemigordius fauna with reference to paleogeographic reconstructions. In most palinspastic reconstructions and schematic diagrams of the Middle Permian, configuration of the large continents is basically the same. The differences usually exist in the region occupied by the large triangular ocean (often called PaleoTethys), where smaller continental blocks are arranged somewhat differently due to the understandings of various authors. The Gondwana-derived blocks are normally placed close to the northern margin of Gondwana, and extend in a NW-SE direction, i.e. the northwest end in tropic (equatorial) region and the southeast end in south temperate region (30-40 south) (e.g. Scotese, 2000; Sengör et al., 1988; Shi \& Archbold, 1998; Ueno, 2003). Such an arrangement of the Gondwana-derived blocks is actually an unavoidable outcome of the reconstruction with a large trianglar Paleo-Tethys, because the northern margin of Gondwana is about $45^{\circ}$ oblique to the equator in this kind of reconstructions.

Normally, the distribution of a fauna is controlled to a great extent by temperature. If this is also true for the ShanitaHemigordius fauna, and the effect of possible ocean currents deflection is not considered, the distribution pattern of this fauna appears to imply that the arrangement of the blocks on which it lived should be, instead of being oblique (about $40^{\circ}$ ) to, more or less parallel to the latitude lines. Moreover, the host rock of the ShanitaHemigordius fauna in Thailand, Burma and western Yunnan are dolomititc limestones with well-developed ooids. These blocks are usually placed at the southeast end of the chain of Gondwanaderived blocks with the highest latitudes. However, the lithology does not indicate that the water temperature on these blocks was correspondingly lower than on the other blocks.

If the Gondwana-derived blocks were in the position as in many palinspastic reconstructions of the Middle Permian, i.e. the northwest end of the block group in tropic (equatorial) region and the southeast end in south temperate region $\left(30-40^{\circ}\right.$ south)(graded diversity patterns of Permian marine faunas across these blocks, i.e. relatively more diversified on the blocks in the northwest than those in the southeast, is considered by some authors to be a result of this alignment or employed as a piece of side evidence for such an alignment, because such an arrangement can result in graded temperature pattern), then at least the widely distributed Shanita amosi must be a temperature-insensitive species and could thrive in environments with different temperatures. This seems not in accordance with some authors' consideration that Shanita is evolved from Hemigordius (but not necessarily H. renzi) (e.g. Brönnimann et al., 1978; Zaninetti, et al., 1982; Gargouri \& Vachard, 1988). This consideration implies that only in certain places (northern margin of Gondwana) this evolvement took place, because Hemigordius occurs not only in the area where Shanita occurs, but also in warm Tethyan regions (e.g. Qinling) and southern Sikhote-Alin.

Ocean currents deflection, which is possible to bring warm water to the blocks at higher latitudes, can on one hand explain, to some extend, the wide distribution of Shanita on Gondwana-derived blocks, when they are arranged with the northwest end of the block group in tropic (equatorial) region and the southeast end in south temperate region ( $30-40^{\circ}$ south), but contradicts on the other hand the conditions required for the graded diversity patterns of Permian marine faunas across these blocks.

At this moment, a satisfactory explanation to the distribution pattern of the Shanita-Hemigordius fauna seems hard to obtain based on the interpretation (reconstruction) that the Gondwanaderived blocks were aligned as a long strip in a NW-SE direction. However, if these blocks were arranged more or less parallel to the latitude lines during the Middle Permian, when the ShanitaHemigordius fauna flourished, and the configuration of large continents remains unchanged, there must be a large ocean between these blocks and Gondwanan continents. However, there is no substantial geological evidence that supports the presence of such a big ocean. Nevertheless, a NW-SE arrangement of Gondwana-derived blocks sometimes may explain certain paleobiogrographic phenomena, such as why elements of neoschagerinids/verbeekinids are present in northwestern part of this block group and absent in the southeastern part (Ueno, 2003).

Such a dilemmatic situation may imply that there are some shortcomings in the fundamentals of the reconstruction. If the configuration of large continents remains unchanged, and the large triangular Paleo-Tethys remains unchanged, it seems very difficult, by means of handling only the continental blocks, to get a satisfactory explanation to many observed geological phenomena in the eastern Tethyside.

\section{Conclusions}

Discrepancies between observed distribution patterns of the ShanitaHemigordius fauna and the established palinspastic reconstructions have been recognized, but a satisfactory explanation is not easily available. Data remain insufficient to permit a revised Permian reconstruction. However, three preliminary conclusions can be reached at this time based on the observed distribution of the Shanita-Hemigordius fauna:

1. The known occurrences of the Shanita-Hemigordius fauna are located mostly on Gondwana-derived blocks, with only a few on the margin of Gondwanan continents.

2. The carbonate rocks containing the Shanita-Hemigordius fauna compose the upper Murgabian-Midian (possibly lower Dzhulfian) part of the Permian successions that start with coarse clastic (mostly glacio-marine) deposits.

3. The Shanita-Hemigordius fauna can be considered as another palaeontological marker of the margin of Gondwana.

\section{Acknowledgements}

This work is supported by a Natural Science Foundation of China (NSFC) grant (No. 40232024). Yao Jinxin and Ji Zhansheng of Institute of Geology, CAGS, Wang Yizhao of Geological Survey of Yunnan, and Yang Hailin of Nanjing University participated in the fieldwork. L. Hance of Carmeuse Coordination Center and Huang Hao of Nanjing University are thanked for providing some needed literature. G. R. Shi of Deakin University, Melbourne is thanked for constructive suggestions, which improved the presentation of the paper. Wang Naiwen of Institute of Geology, CAGS is thanked for some discussions and translating Russian literature.

\section{References}

Altiner, D., Özcan-Altiner, S. and Koçygit, A., 2000, Late Permian foraminiferal biofacies belts in Turkey: palaeogeographic and tectonic implications. In: Bozkurt, E., Winchester, J. A. \& Piper, J. D. A. (eds.), Tectonics and magmatism in Turkey and the surrounding area. Geological Society Special Publications, London, 173, 83-96.

Baghabani, D., 1988, Shanita zone and its biostratigraphic significance in south and southwest Iran. Revue de Paleobiologie, Vol. Spec. No. 2, Benthos' $86,37$.

Brönnimann, P., Whittaker, J. E. and Zaninetti, L., 1978, Shanita, a new pillared miliolacean foraminifer from the Late Permian of Burma and Thailand. Rivista Italiana di Paleontologia e Stratigrafia, 84 (1): 63-92. 
Dawson, O., Racey, A. and Whittaker, J. E., 1993, The palaeoecological and palaleobiogeographic significance of Shanita (foraminifera) and associated foraminifera/algae from the Perpian of penisular Thailand. International Symposium on biostratigraphy of aminland Southeast Asia: facies \& palaeontology, Chiangmai, Thailand, 283-295.

Gargouri, S. and Vachard, D., 1988, On Hemigordiopsis and other porcelaneous foraminifera from Jebel Tebaga (Upper Permian, Tunisia). Revue de Paleobiologie, Vol. Spec. No. 2, Benthos'86, 57-68

Jin, X., 1996, Tectono-stratigraphic units in western Yunnan and their counterparts in Southeast Asia. Continental Dynamics, 1(2), 123-133.

Jin, X., 2002, Permo-Carboniferous depositional sequences of Gondwana affinity in southwest China and their paleogeographic implications, Journal of Asian Earth Sciences, 20(6), 633-646.

Jin, Y., Wardlaw, B. R., Glenister, B. F., Kotlyar, G. V., 1997, Permian chronostratigraphic subdivisions, Episodes, 20(1), 10-15.

Ingavat, R., 1984, On the correlation of the Permian foraminiferal faunas of the western, central and eastern provinces of Thailand. Mémoires de la societe géologique de france, N. S., 147, 73-100.

Leven, E. Ja., 1991, Pervye nakhodki v SSSR foraminifer roda Shanita (Semeyestvo Hemigordiopsidae), Paleontol. Zhur. 2, 102-104 (in Russian)

Leven, E. Ja., 1993, Early Permian fusulinids from the Central Pamir. Rivista Italiana di Paleontologia e Stratigrafia, 99 (2): 151-198.

Leven, E. Ja., 1997, Permian stratigraphy and Fusulinida of Afghanistan with their paleotectonic implications. Geological Society of America Special Paper, 316, 1-134.

Metcalfe, I., 1996, Pre-Cretaceous evolution of SE Asian terranes. In Hall, R. \& Blundell, D. (eds.), Tectonic Evolution of Southeast Asia, Geological Society Special Publication, London, 106, 97-122.

Montenat, C., Lapparent, A. F. de, Lys M., Termier, H., Termier, G. and Vachard, D., 1976, La transgression permienne et son substratum dans le Jebel Akhdar (Montagnes d'Oman, Peninsule Arabique). Annales Societe Geologique du Nord, Lille, 96(3), 239-258.

Nestell, M. K. and Pronina, G. P., 1997, The distribution and age of the Genus Hemigordiopsis. In: Ross, C. A., Ross, J. R. P. \& Brenckle, P. L. (eds.), Late Paleozoic Foraminifera; their biostratigraphy, evolution, and paleoceology; and the Mid-Carboniferous boundary, Cushman Foundation for Foraminiferal Research, Special Publicaion 36, 105-110.

Nie, Z.and Song, Z., 1985, Foraminiferal assemblage of Lower Permian Maokouan Longge Formation in Rutog, Ngari area, Tibet. Contributions to the geology of the Qinghai-Xizang (Tibet) Plateau, 17, 199-222 (in Chinese with English abstract)

Nikitina, A. P., 1969, Hemigordiopsis (Foraminifera) in the Upper Permian of the Maritime Territory. Paleontological Journal (English translation of Paleonto. Zhur.) 3, 341-346.

Okay, A. O., 2000, Was the Late Triassic orogeny in Turkey caused by the collision of an oceanic plateau? In: Bozkurt, E., Winchester, J. A. \& Piper, J. D. A. (eds.), Tectonics and magmatism in Turkey and the surrounding area. Geological Society, London, Special Publications, 173, 25-42.

Pronina, G. P., 1988, The Late Permian smaller foraminifera of Transcaucacus. Revue de Paleobiologie, Vol. Spec. No. 2, Benthos'86, 89-96.

Reichel, M., 1945, Sur un Miliolidé nouveau du Permien de l'île de Chypre. Verhandlungen der Naturforschenden Gesellschaft in Basel, 56, 521-530.

Scotese, C. R., 2000, Atlas of Earth History: Paleogeographic Maps, Arlington, Texas, 1-52.

Sengör, A. M. C., 1984, The Cimmeride orogenic sysmtem and the tectonics of Eurasia. Geological Society of America Special Paper, 195, 1-82.

Sengör, A. M. C., Altiner, D., Cin, A., Ustaömer, T. and Hsü, K. J., 1988, Origin and assembly of the Tethyside orogenic collage at the expense of Gondwanaland. In Audley-Charles, M.G. \& Hallam, A. (eds.) Gondwana and Tethys, geological Society Special Publication, 37, 81-119.

Sengör, A. M. C. and Natal'in, B. A., 1996, Paleotectonics of Asia: fragments of a synthesis. In: Yin, A. \& Harrison, M. (eds.), The tectonic evolution of Asia, Cambrage Press, 486-640.

Sheng, J. Z. and He, Y., 1983, Permian Shanita - Hemigodius (Hemigordiopsis) (Foraminifera) fauna in western Yunnan, China. Acta Palaeontologica Sinica, 22(1):55-59 (in Chinese with English abstract).

Shi, G. R. and Archbold, N. W., 1998, Permian marine biogeography of SE Asia. In: Hall, R. \& Holloway, J. D. (eds.), Biogeography and Geological Evolution of SE Asia, Backhuys Publishers, Leiden, 57-72.

Ueno, K., 2003, The Permian fusulinoidean faunas of the Sibumasu and Baoshan blocks: their implications for the paleogeographic and paleocli- matologic reconstruction of the Cimmerian Continent. Palaeogeography Palaeoclimatology Palaeoecology, 193, 1-24

Wang, G. and Sun, X., 1973, Carboniferous and Permian Foraminifera of the Chinling Range and its geologic significance, Acta Geologica Sinica, 47(2):137-178 (in Chinese).

Wang, K., 1982, Carboniferous and Permian Foraminifera of Xizang. In: Team of the Scientific Expedition to the Qinghai-Xizang Plateau (ed.) Palaeontology of Xizang, Book IV, Beijing: Science Press, 1-32 (in Chinese).

Whittaker, J., Zaninetti, L. and Altiner, D., 1979, Further remarks on the micropalaeontology of the late Permian of eastern Burma. Notes du Laboratore de Paleontologie de l'Universite de Geneve, 5(2): 11-18.

Yang, X., Jin, X., Ji, Z., Wang, Y., Yao, J. and Yang, H., 2004, New materials of the Shanita-Hemigordius Assemblage (Permian Foraminifers) from the Baoshan Block, western Yunnan. Acta Geologica Sinica, 78(1) $15-21$.

Zaninetti, L., Altiner, D., Catal, E. and Decrouez, D., 1982, Shanita bronnimanni, n. sp., (Hemigordiopidae, Foraminiferida), dans le Permian Supereur du Tarus Oriental, Turquie: Un exemple d'adaptation structurale a l'evolution regressive de la cavite locularie chez les grands foraminiferes porcelanes du Paleozoique. Revue de Paleobiologie, 1(1) 29-36.

Zaninetti, L., Whittaker, J. and Altiner, D., 1979, The occurrence of Shanita amosi Brönnimann, Whittaker \& Zaninetti (Foraminiferida) in the late Permian of the Tethyan region. Notes du Laboratore de Paleontologie de l'Universite de Geneve, 5(1): 1-7.

Xiaochi JIN, born in 1961. Professor at Institute of Geology, Chinese Academy of Geological Sciences. Received his Bachelor of Science degree from Nanjing University in 1982; Master of Science degree from Graduate School of Chinese Academy of Geological Sciences in 1985; Doctor of Science degree from University of Cologne, Germany in 1994. He is presently active in the fields of stratigraphy, sedimentology and paleogeography of Yunnan and the Qinghai-Tibet Plateau.

Xiangning YANG, born in 1956. Professor at the Department of Earth Sciences, Nanjing University. Graduated from Nanjing University in 1979. Received his Master of Science degree from the same University in 1982; Doctor degree from Johns Hopkins University, USA in 1986. Carried out PostDoctor research at China University of Geosciences, Beijing, 1987-1989. His work now is focused on paleobiology of foraminifers and Permo-Carboniferous stratigraphy.
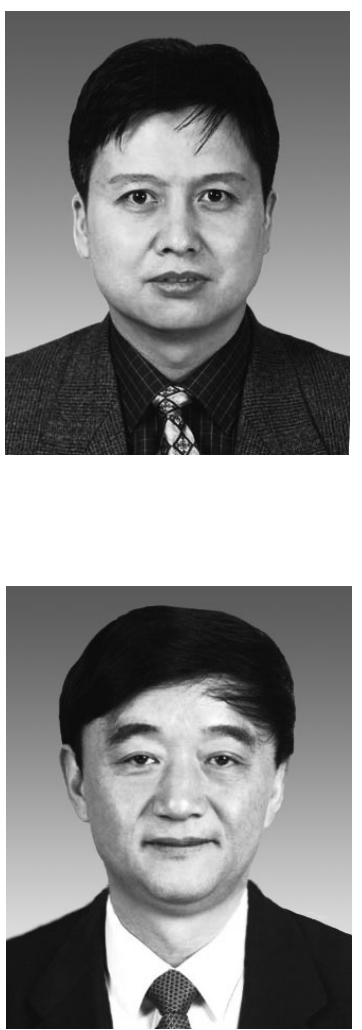